\title{
An annotated key to the species of Gastridium (Poaceae) with distributional novelties to the Italian territory
}

\author{
Anna Scoppola
}

\begin{abstract}
Gastridium is a Mediterranean-paleotropical genus of the Poaceae family, native to Italy. Species number and diversity were imperfectly known until recent taxonomic updates on morphological and molecular basis that enhanced our knowledge of this taxon. The present contribution provides a complete key of the genus, encompassing the four currently known closely related species, $G$. lainzii, $G$. phleoides, G. scabrum, and G. ventricosum. The essential features of panicle, spikelets, and florets are specified and briefly discussed. Revisions of ancient and recent herbarium specimens provided three Italian distributional novelties for G. phleoides concerning Liguria, Campania, and Puglia and two for G. scabrum concerning Liguria and Basilicata. In contrast, the distributional ranges of G. scabrum and G. lainzii in the $\mathrm{W}$ Mediterranean region remain poorly known and await further investigations.
\end{abstract}

Key words: Gastridium, identification key, Italy, new records, Spain, taxonomic characters.

Riassunto - Una chiave annotata per le specie di Gastridium (Poaceae) con novità circa la sua distribuzione nel territorio italiano.

Gastridium è un genere mediterraneo-paleotropicale della famiglia delle Poaceae, autoctono in Italia. Il numero e la diversità di specie erano conosciuti in modo imperfetto fino ai recenti aggiornamenti tassonomici su base morfologica e molecolare che hanno migliorato le nostre conoscenze su questo taxon. Il presente contributo fornisce una chiave completa del genere, che comprende le quattro specie attualmente conosciute, strettamente correlate, G. lainzii, G. phleoides, G. scabrum e G. ventricosum. Vengono indicate e brevemente discusse le caratteristiche essenziali di pannocchia, spighette e fiori. La revisione di antichi e recenti esemplari di erbario ha fornito per il territorio italiano tre novità distributive relative a $G$. phleoides riguardanti Liguria, Campania e Puglia e due relative a G. scabrum riguardanti Liguria e Basilicata. Al contrario, gli areali di G. scabrum e G. lainzii nella regione mediterranea occidentale rimangono poco conosciuti e richiedono ulteriori indagini.

Parole chiave: caratteri tassonomici, chiave di identificazione, Gastridium, Italia, nuove segnalazioni, Spagna.

Department of Agriculture and Forestry Sciences (DAFNE), Tuscia University, via S. Camillo De Lellis, 01100 Viterbo, Italia.

E-mail: scoppola@unitus.it

(C) 2019 Anna Scoppola

Received: 23 July 2019

Accepted for publication: 19 September 2019

Online publication: 4 November 2019

\section{INTRODUCTION}

Gastridium P.Beauv. is a Mediterranean-paleotropical genus (Pignatti, 1982; Bolòs \& Vigo, 2001) of the Poaceae family (subfamily Pooideae Benth., tribe Poeae R.Br., subtribe Agrostidinae Fr.), sister of the monotypic, Mediterranean and Irano-Turanian genus Triplachne Link (Clayton \& Renvoize, 1986; Quintanar et al., 2007; Saarela \& Graham, 2010; Soreng et al. 2015). It is represented by few, somewhat similar, annual species inhabiting ephemeral grasslands, shrubby pastures, garrigues, forest clearings, hedges, path sides (Scoppola \& Cancellieri, 2019). According to Kellogg (2015), the genus comprises two traditionally well-known species from Europe, North Africa, and the Middle East: the Circum-Mediterranean-Paleotropical G. ventricosum (Gouan) Schinz \& Thell. (三Agrostis ventricosa Gouan), and the (Steno)-Mediterranean G. phleoides (Nees \& Meyen) C.E.Hubb (三Lachnagrostis phleoides Nees \& Meyen) (cf. Doğan, 1985; Scholz, 1986, 1998; Scoppola et al., 2017; Romero García, 2019). Nevertheless, literature on Mediterranean flora consistently shows evidence of additional morpho-ecological variation within the genus, suggesting the occurrence of further taxa, generally overlooked in taxonomic authorities such as IPNI (www.ipni.org), The Plant List (www.theplantlist. org), and Tropicos (www.tropicos.org), all accessed on March 2019, and in some major treatments (Scholz, 1986; Valdés \& Scholz, 2009; Le Floch et al., 2010). An improved taxonomic framework of the genus was recently derived from the patterns of DNA diversity existing at two plastid (trnH-psbA, trnL-F) and one nuclear (ITS) DNA markers (Cardoni \& Simeone in litt., 2019). Notably, this study demonstrated that morphological diversity has consistent molecular grounds in both genomes, and likely subtend the existence of more objective species than currently acknowledged. Authors of some traditional and recent Mediterranean floras regarded as distinct species of the genus Gastridium three entities (e.g., Doğan, 1985; Feinbrun-Dothan, 1986; Dimopoulos et al., 2013; Tison \& De Foucault, 2014; Tison et al., 2014; Pignatti, 2017). This additional entity is the $\mathrm{N}$ Steno-Mediterranean G. scabrum C.Presl, whose name was either treated as a heterotypic synonym of $G$. ventricosum or even included in it as an illegitimate or an invalid name (cf. Tutin, 1980; Valdés \& Scholz, 2009; 
WCSP, 2018; Romero García, 2019). It was validly and effectively published in 1818 by C. Presl, as highlighted by Scoppola \& Cancellieri (2019) who also confirmed a taxonomically satisfying circumscription of G. scabrum at the species level and provided useful morphological characters discriminating the three species. A fourth species, G. lainzii (Romero García) Romero Zarco (三 Gastridium phleoides subsp. lainzii Romero García), has the most restricted distribution area within the genus and is still treated as a subspecies of G. phleoides in the quoted taxonomic authorities. It is known to occur on SW Iberian Peninsula, in Badajoz, Cordoba, Huelva, Malaga, Seville and Cadiz Provinces and on N Morocco (Romero García, 1996, 2019; Romero Zarco, 2013; López Tirado \& Scoppola, 2017), although Pike (2007) has proposed to extend its distribution also to Portugal. In the Iberian Peninsula G. phleoides and G. ventricosum are also known and regarded as distinct species (Romero García, 2019), while G. scabrum is treated as a synonym of $G$. ventricosum. All three species have been reported within the Italian territory (Giardina et al., 2007; Arrigoni, 2015; Pignatti, 2017; Bartolucci et al., 2018), where the occurrence of G. scabrum in Tuscany and G. phleoides in Campania remains somewhat unclear (Bartolucci et al., 2018). No author has ever questioned the specific autonomy or given doubtful occurrences, of $G$. ventricosum. The close relationships highlighted between Triplachne nitens (Guss.) Link and Gastridium, particularly G. lainzii (Quintanar et al., 2007; Saarela \& Graham, 2010; Saarela et al., 2017; Cardoni \& Simeone in litt., 2019) reflect previous ideas and current observations about their morpho-ecological similarity (Clayton \& Renvoize, 1986; Romero García, 1996; Pyke, 2008; Scoppola \& Cancellieri, 2019) that even led Romero Zarco (2015) to include Triplachne within Gastridium (G. nitens (Guss.) Coss. \& Durieu). Their precise affinities and the possible role of $T$. nitens in the origin of $G$. lainzii still remain unclear.

The main obstacles to an unambiguous solution of current knowledge gaps can be tracked both in the considerable, sometimes overlapping variation exhibited by some diagnostic characters traditionally reported in literature (e.g., panicle shape, ligule length; cf. Scholz, 1986; Jauzein, 2003) and in the incomplete keys that have complicated the task of identifying old and new material, thus increasing confusion. Even the recent revision by Scoppola \& Cancellieri (2019) did not include a full key of the genus. Accordingly, the present contribution aims to provide an updated identification key to the species of the genus Gastridium at a European scale, including Triplachne, and to refine its Italian distribution through a critical examination of selected specimens from some main herbaria, and recent plant collections from central Italy.

\section{MATERIALS AND METHODS}

Specimens belonging to the Mediterranean Gastridium taxa were selected among the revised exsiccata in CLU, FI, GE, HLUC, MSNM, PAL, PI, RO, SIENA, SS, UTV herbaria (acronyms according to Thiers, 2018). The specimens of $G$. lainzii, recently collected for our mole- cular taxonomic studies, were also selected from UTV. Caryopses of G. scabrum from central Italy and Turkey were germinated in the greenhouse for subsequent observations. High-definition images of glumes and dispersal units of $G$. lainzii were obtained using a Leica IC80 HD digital camera under a Leica M60 stereo-microscope and processed using the application LAS V-3.8. Images of the other species were selected from our archives. Species delimitation was performed based on Scoppola \& Cancellieri (2019) and by means of a critical examination of relevant and type material available in the herbaria B, CAS, HAL, PRC, SE, and W (online). Unfortunately, the type of $G$. ventricosum (lectotype indicated by Doğan 1985: 359: A. Gouan in K) could not be checked. Overall, more than 200 specimens were revised. The most significant are reported in the 'Selected specimens examined' section.

\section{IDENTIFICATION KEY TO THE SPECIES OF THE GENUS GASTRIDIUM, INCLUDING THE GENUS TRIPLACHNE}

The present key refers to a comprehensive combination of reliable features allowing a consistent circumscription of the four species. It can be useful for a quick recognition of Gastridium variability at a larger scale. It mostly results from the check of fresh and dried material (see 'Selected specimens examined') and of several digital images used in previous studies, as well as from the essential features published by Scoppola \& Cancellieri (2019), and by previous partial keys. More specifically, all species have dense (or lobed) spiciform panicles (Fig. 1) with 1-flowered awned and unawned spikelets, with a different rate of heterodiaspory (Tzveley, 1976; Scholz, 1986) in any given panicle. Surprisingly, in the recent Flora d'Italia (Pignatti, 2017, 2019) the heterodiaspory has not been properly interpreted: the key first splits the species based on the presence, in the same panicle, of only awned ( $G$. ventricosum, $G$. phleoides) or unawned lemmas ( $G$. scabrum, "resta mancante"), as also reported by Tison et al. (2014), thus indicating G. scabrum as having only unawned florets. Our observations provide for this species 2-5\% of awned spikelets in agreement with Tzvelev (1976).

The main diagnostic characters (to be observed on spikelets with mature caryopses) are summarized as follows: 1) The dorsal awn position: in Gastridium just below the apex of the lemma (subterminal), in Triplachne from near the base. 2) Glumes shape and length (Fig. 1): half the width of glumes measured at $1 \mathrm{~mm}$ from the apex was significantly different among species (even more if associated to the glume length), and determinant in distinguishing G. phleoides from G. scabrum. 3) The awn length and consequently the awn portion protruding from panicle: it is determinant in distinguishing G. phleoides and $G$. lainzii from $G$. ventricosum; note that the measures reported for the various species could be affected by underestimates derived from measurements of not entirely mature florets. 4) The dense roughness on the lemma surface: it can be used to distinguish $G$. ventricosum from the other species (Fig. 2). 5) The hairiness (hairs or bristles) pattern on the lemma surface in both awned and unawned florets (Fig. 2); note that data on the hairiness of unawned 

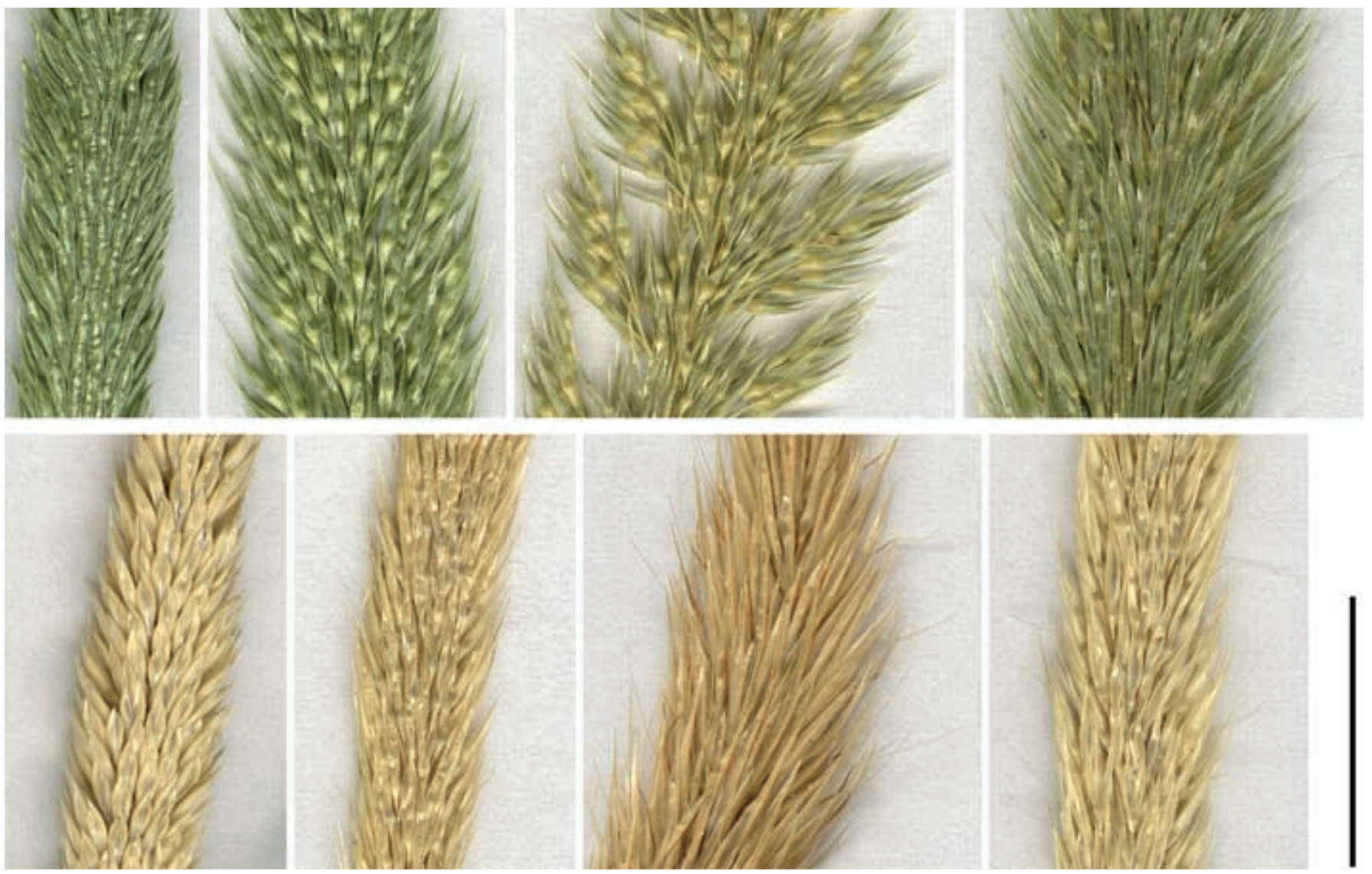

Fig. 1 - Comparison of the panicle details in the studied species. From left to right, above: G. scabrum, G. ventricosum (dense), G. ventricosum (lobed); G. phleoides; below: G. scabrum; G. ventricosum, G. lainzii, G. phleoides. The images were obtained using a high-resolution flatbed digital scanner (scale bar $=1 \mathrm{~cm}$ ).

lemmas in G. lainzii are based only on observations of the material in UTV as no information is reported in the literature. 6) The awned lemmas with four evident setae at the apex of which the laterals are larger, in addition to the dorsal subterminal awn: this character is determinant to distinguish $G$. lainzii from the other congeners and from Triplachne.

\section{Identification key}

1 - Panicles narrow, cylindrical, dense to lobed; glumes clearly swollen below; lemma with a geniculate dorsal awn rising (when present) just below the apex ..... 2

2 - Glumes lanceolate, narrow (half the width of the upper glume $0.20-0.27 \mathrm{~mm}$ by mean), scabrid mostly on the keel, unequal in both spikelet types; lower glume acuminate-subulate. Most florets with awned and hairy/bristly lemmas. Spiciform panicles usually well-spaced, lax and lobed during anthesis, with spikelets shortly (or not) pedicellate ................................... 3

3 - Lower glume (3.0) 3.5-5.5 mm, acuminate; upper glume 2.5-3.5 (4.0) mm. Lemma surface always densely, minutely rough upwards (slightly tuberculate at magnification $\times 40$ ); hairiness (when present) distributed only on the upper third of lemma, margins or callus, never on the whole surface. Awn (2.0) 2.5-4.5 (5.0) mm, scarcely protruding from panicle. Caryopsis obovate-elliptic. Ligule of the upper leaves usually short (2.0-4.0 mm)

\section{Gastridium ventricosum}

3' - Glumes larger; lower glume subulate. Lemma surface smooth and with a different distribution pattern of hair and bristles. Awn larger and greatly protruding from panicle. Caryopsis elliptic-fusiform. Ligule of the upper leaves usually longer $(3.0-7.0 \mathrm{~mm}) \ldots \ldots \ldots \ldots \ldots \ldots .4$

4 - Lower glume 4.5-7.5 mm, upper glume (3.0) 3.5-6.0 (6.5) $\mathrm{mm}$. Lemmas 1.0-1.5 mm: awned lemma entirely bristly, truncate-toothed at the apex (setae max $0.1 \mathrm{~mm}$ ); unawned lemmas completely, or rather completely, smooth, entirely densely bristly or glabrous. Awn (4.0) 4.5-7.5 $\mathrm{mm}$

\section{Gastridium phleoides}

4' - Lower glume 6.0-7.0 (7.5) mm; upper glume 4.55.0 (6.0) mm. Awned lemma 1.5-2.3 (2.5) mm, entirely bristly, toothed at the apex by four setae of which the laterals are larger $(0.5-1.0 \mathrm{~mm})$; unawned lemmas smooth and predominantly glabrous, shorter, and toothed at the apex. Awn 7.5-8.0 (9.0)

Gastridium lainzii

2' - Glumes broadly lanceolate (half the width of the upper glume $0.34-0.37 \mathrm{~mm}$ by mean), scabrid on the surface and keel, sub-equal at least in unawned spikelets; lower glume merely acute, $3.0-5.0 \mathrm{~mm}$, upper glume 
(2.0) 2.5-4.0 mm. Most of the florets with unawned lemmas, glabrous and smooth; awned lemmas (awn 3.5-5.0 mm) usually entirely densely bristly. Spiciform panicles usually slightly spaced, rather contracted even during flowering, with spikelets densely overlapping .

Gastridium scabrum

1 ' - Panicles dense, ovoid to fusiform; glumes not clearly swollen below; lemma with a geniculate dorsal awn from near the base and two outer, long, apical setae, about as long as lemma

Triplachne nitens

\section{Italian distributional novelties}

The possible cause of knowledge gaps and doubts reported in the Italian literature over the years (Pignatti, 1982, 2017; Scholz, 1998; Conti et al., 2005; Giardina et al., 2007) was the problematic identification of $G$. phle- oides compared to the closest congeneric G. ventricosum. This statement is easily deduced from Table 1 in Scoppola $\&$ Cancellieri (2019) suggesting that over $40 \%$ of the names under which the specimens (both ancient and current) were stored in the quoted herbaria was different from the concerned species, and the percentage rises to $88 \%$ considering only $G$. phleoides.

G. phleoides was already cited for Veneto (Masin \& Tietto, 2006) and Sardinia (Scholz, 1998; Lazzeri et al., 2013). Our revisions and field surveys started in 2015 and led to reporting the species in Tuscany, Lazio, Campania (only ancient data), Calabria, and Sicily (Scoppola et al., 2017). The new Italian Checklist (Bartolucci et al., 2018) has further updated its occurrence, confirming this distribution. Based on the latest revisions, a new update is here provided for $G$. phleoides, with three new regional records in mainland Italy. The historical
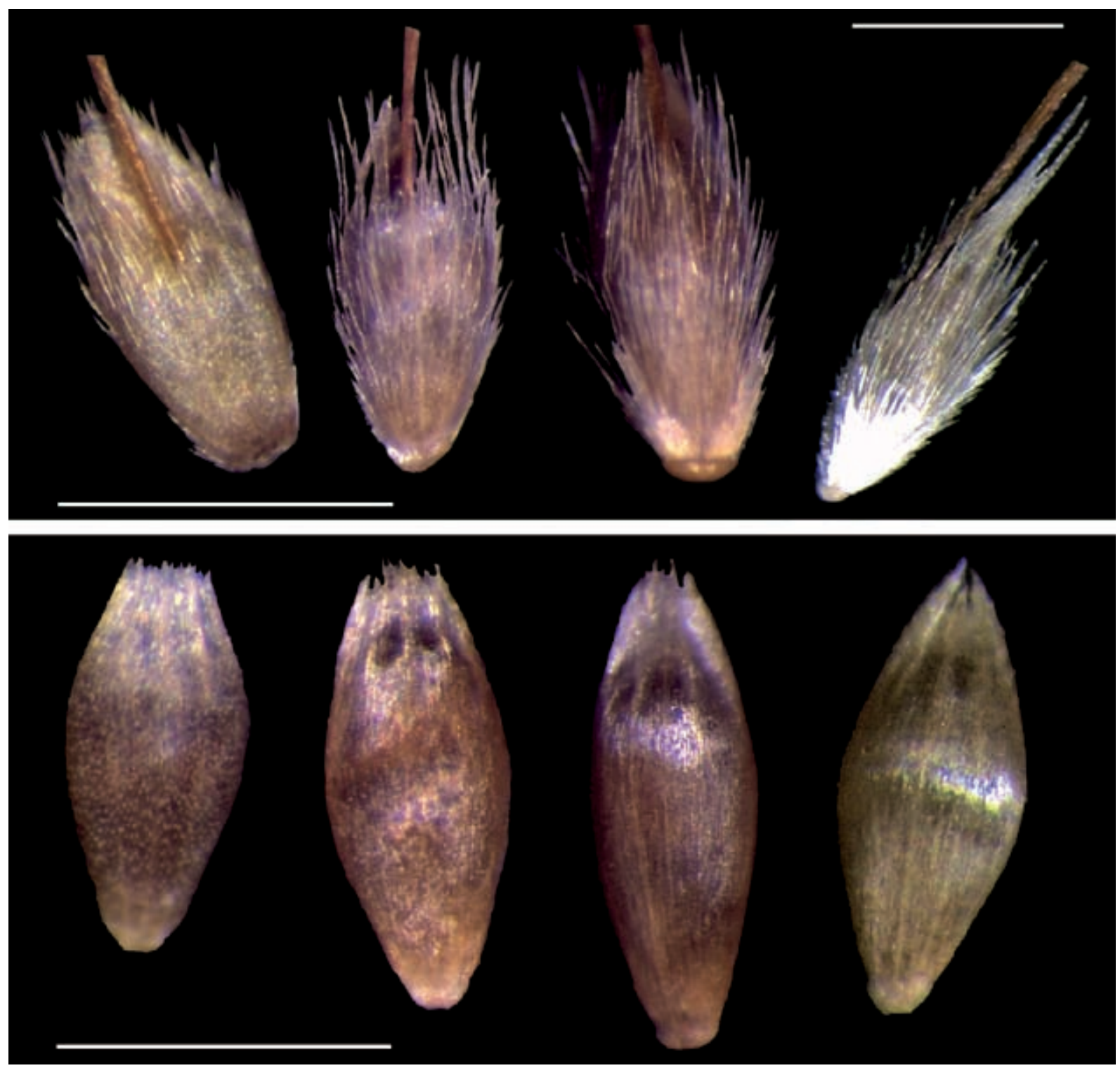

Fig. 2 - Distribution patterns of hairiness and roughness in the awned (above) and unawned (below) dispersal units of the studied species. From left to right: G. ventricosum; G. phleoides; G. scabrum; G. lainzii. The photos were taken using a stereomicroscope with integrated high-resolution digital camera (scale bar $=1 \mathrm{~mm}$ ). 
presences in Liguria (Varazze, 1923, legit Gresino) and Puglia (Leucaspide, 1877, legit Profeta; Otranto, 1880, legit Profeta) are due to specimens revised in FI. The record in Puglia has been confirmed by recent occurrences highlighted by three exsiccata in MSNM (Capo d'Otranto, 1986, legit Banfi sub G. scabrum; S. Isidoro, 1991, legit Banfi; Salento, 1992, legit Galasso sub G. ventricosum). The ancient presence in Campania is here confirmed by a specimen revised in HLUC (Acciaroli, Cilento, 2004, legit Rosati G. ventricosum) and the recent finding by A. Stinca (Caserta, 2016, PORUN). The wide diffusion of $G$. phleoides on the middle and lower Tyrrhenian side, including islands, is supported by many other specimens (ancient and recent) found in the quoted herbaria and coming from Tuscany, Lazio, Calabria, Sicily, and Sardinia (see 'Selected specimens examined').

According to Bartolucci et al. (2018), G. scabrum is confirmed in Lazio, Molise, Puglia, Calabria, Sicily, and Sardinia. We could not find recent specimens about from Sardinia, although the species was already mentioned by Pignatti (1982) and by Conti et al. (2005). The possible presence on Elba island, originally reported by Sommier (1903) and not confirmed thereafter (cf. Carta et al., 2018), remains to be validated by future findings. We report two new records for Liguria and Basilicata. The first is related to an ancient regional presence due to old specimens, correctly identified, preserved at GE and FI (Bordighera, 1901, Herb. Bicknell); its current presence, therefore, requires confirmation. The second refers to a unique sample, correctly identified, stored at HLUC (Trivigno, 1979, legit Aita) which, although presenting a good affinity to G. scabrum, shows a slightly rugged surface of the lemmas (possible transitional form towards G. ventricosum?). G. scabrum is somewhat rare in mainland Italy and the main islands (Pignatti, 2017), as well as in France, where it is considered in regression (Tison et al., 2014).

\section{CONCLUSIONS}

Based on the above considerations, we believe that the newly provided key can allow a better assessment of the distribution of the genus. Overall, the knowledge of $G$. scabrum in the W Mediterranean region needs more accurate field research; in Italy, it could be found for example in the dry pastures on the clays of the sub-coastal plains of Tuscany and Campania and deserves to be confirmed in Sardinia. New records are also required to precisely evaluate the distribution of $G$. phleoides, currently spreading in the Mediterranean area. It should be searched for example in the uncultivated thermophilous and semi-ruderal grasslands in Molise and Basilicata, on siliceous sandy soils. Our current field studies are focused on clarifying unresolved issues and updating records on both species. G. ventricosum remains, however, the most widespread in the whole Italian territory.

Finally, special efforts are needed to explore the real distribution of $G$. lainzii in the W Mediterranean, taking in proper consideration that only a careful check can help to distinguish this species from G. phleoides.

\section{Acknowledgements}

The author is grateful to the directors and curators of the quoted Herbaria for making the collections available for the study, to M. Pellegrino for the high-resolution digital images of G. lainzii floral details, to F. Bartolucci, L. Bernardo, L. Cancellieri, G. Domina, S. Peccenini, L. Peruzzi, L. Rosati, A. Stinca for useful information, to G. Galasso for improving the manuscript through his comments. The study was carried out in the framework of the MIUR (Italian Ministry for Education, University, and Research) initiative, Law 232/2016, Department of excellence.

\section{REFERENCES}

Arrigoni P.V., 2015 - Flora dell'isola di Sardegna. 6. Carlo Delfino Editore, Sassari.

Bartolucci F., Peruzzi L., Galasso G, Albano A., Alessandrini A, Ardenghi N.M.G., Astuti G., Bacchetta G., Ballelli S., Banfi E., Barberis G., Bernardo L., Bouvet D., Bovio M., Cecchi L., Di Pietro R., Domina G., Fascetti S., Fenu G., Festi F., Foggi B., Gallo L., Gottschlich G., Gubellini L., Iamonico D., Iberite M., Jiménez-Mejías P., Lattanzi E., Marchetti D., Martinetto E., Masin R.R., Medagli P., Passalacqua N.G., Peccenini S., Pennesi R., Pierini B., Poldini L., Prosser F., Raimondo F.M., Roma-Marzio F., Rosati L., Santangelo A., Scoppola A., Scortegagna S., Selvaggi A., Selvi F., Soldano A., Stinca A., Wagensommer R.P., Wilhalm T. \& Conti F., 2018 - An updated checklist of the vascular flora native to Italy. Plant Biosystems, 152 (2): 179-303.

Bolòs O. \& Vigo J., 2001 - Flora dels Països Catalans. Editorial Barcino, Barcelona, 4.

Carta A., Forbicioni L., Frangini G., Pierini B. \& Peruzzi L., 2018 - An updated inventory of the vascular flora of Elba island (Tuscan Archipelago, Italy). Italian Botanist, 6: 1-22.

Clayton W.D. \& Renvoize S.A., 1986 - Genera Graminum. Grasses of the world. Kew Bulletin, Additional Series, 13: 1-389.

Conti F., Abbate G., Alessandrini A. \& Blasi C. (eds.) 2005 - An annotated checklist of the Italian vascular flora. Palombi Editori, Roma.

Dimopoulos P., Raus T., Bergmeier E., Constantinidis T., Iatrou G., Kokkini S., Strid A. \& Tzanoudakis D., 2013 - Vascular plants of Greece: An annotated checklist. Botanic Garden and Botanical Museum Berlin-Dahlem, Berlin; Hellenic Botanical Society, Athens.

Doğan M., 1985 - Gastridium P. Beauv. In: Flora of Turkey and the East Aegean Islands. Davis P.H. (ed.). Edinburgh University Press, 9: 358-360.

Feinbrun-Dothan N., 1986 - Flora Palestina. Israel Academy Sciences and Humanities, Jerusalem, 4: 217-218.

Giardina G., Raimondo F. \& Spadaro V., 2007 - A catalog of plants growing in Sicily. Bocconea, 20: 3-582.

Jauzein P., 2003 - Contribution à la connaissance du genre Gastridium Beauv. en France. Le Monde des Plantes, 481: 1-3. 
Kellogg E.A., 2015 - Subfamily Pooideae Benth. (1861). In: Flowering Plants. Monocots: Poaceae. The Families and Genera of Vascular Plants. Kubitzki K. (ed.). Cham, 13: 199-265.

Lazzeri V., Mascia F., Sammartino F., Campus G., Caredda A., Carlesi V., Fois M., Gestri G., Mannocci M., Mazzoncini V., Cuena Lombraña A. \& Santinelli M., 2013 - Novità floristiche per le regioni Sardegna e Toscana. Acta Plantarum Notes, 2: 42-59.

Le Floc'h É., Boulos L. \& Véla E., 2010 - Catalogue synonymique commenté de la Flore de Tunisie. République Tunisienne. Ministère de L'Environnement et du Développement Durable, Banque Nationale De Gènes.

López Tirado J. \& Scoppola A., 2017 - Gastridium lainzii (Romero García) Romero Zarco (Poaceae), novedad corológica para la provincia de Cádiz (España). Revista de la Sociedad gaditana de Historia Natural, 11: 55-56.

Masin R. \& Tietto C., 2006 - Flora vascolare della provincia di Padova. Natura Vicentina, 9 (2005): 7-103.

Pignatti S., 1982 - Flora d'Italia. Edagricole, Bologna, 1.

Pignatti S., 2017 - Flora d'Italia. Edagricole-New Business Media, Milano, 1.

Pignatti S., 2019 - Flora d'Italia. Edagricole-New Business Media, Milano, 4.

Pyke S., 2008 - Gastridium phleoides (Gramineae) en Cataluña. Collectanea Botanica, 27 (2008): 91-94.

Presl C.B., 1818 - Gramineae Siculae. Dissertatio inauguralis medico-botanica. Typus sommerianis, Prague.

Quintanar A., Castroviejo Bolibar S. \& Catalán P., 2007 Phylogeny of the tribe Aveneae (Pooideae, Poaceae) inferred from plastid trnT-F and nuclear ITS sequences. American Journal of Botany, 94: 1554-1569.

Romero García A.T., 1996 - Un taxón nuevo del género Gastridium P. Beauv. (Gramineae) en Andalucía occidental (España). Anales del Jardín Botánico de Madrid, 54 (1): 399-406.

Romero García A.T., 2019 - Gastridium P. Beauv., versión 2bis. In: Gramina Iberica. Genera graminum in opus "Flora iberica" intendentes. Romero-Zarco C. (ed.). <https://sites.google.com/site/graminaiberica> (retrieved on April 2019).

Romero Zarco C., 2013 - Notas sobre gramíneas del N de Marruecos. Acta Botanica Malacitana, 38: 224-227.

Saarela J.M. \& Graham S.W., 2010 - Inference of phylogenetic relationships among the subfamilies of grasses (Poaceae: Poales) using meso-scale exemplar-based sampling of the plastid genome. Botany, 88: 65-84.

Saarela J.M., Bull R.D., Paradis M.J., Ebata S.N., Peterson P.M., Soreng, R.J. \& Paszko B., 2017 - Molecular phylogenetics of cool-season grasses in the subtribes Agrostidinae, Anthoxanthinae, Aveninae, Brizinae, Calothecinae, Koeleriinae and Phalaridinae (Poaceae: Pooideae: Poeae: Poeae chloroplast group 1). Phytokeys, 87.

Scholz H., 1986 - Bemerkungen zur Flora Griechenlands: Gastridium phleoides und G. ventricosum (Poaceae). Willdenowia, 16 (1): 65-68.
Scholz H., 1998 - Gastridium phleoides (Nees \& Meyen) C.E.Hubb. In: Med-Checklist Notulae 17. Greuter W. \& Raus T. (eds.). Willdenowia, 28: 171.

Scoppola A., López Tirado J., Navarrete Martinez R. \& Cancellieri C., 2017 - Contributo alla conoscenza del genere Gastridium (Poaceae) in Italia. Identità e distribuzione di G. phleoides. Notiziario della Società Botanica Italiana, 1: 195-196.

Scoppola A. \& Cancellieri L., 2019 - A comparative morphometric study of genus Gastridium P. Beauv. (Poaceae) and its implications for species delimitation. Nordic Journal of Botany, 37 (9). < doi: 10.1111/ njb.02377>.

Sommier S., 1903 - La flora dell'Arcipelago Toscano. Nota II. Nuovo Giornale Botanico Italiano, nuova serie, 10 (2): 187.

Soreng R.J., Peterson P.M., Romaschenko K., Divides G., Zuloaga F.O., Judziewicz E.J., Filgueiras T.S., Davis J.I. \& Morrone O., 2015 - A worldwide phylogenetic classification of the Poaceae (Gramineae). Journal of Systematic Evolution, 53 (2): 117-137.

Thiers B., 2018 continuously updated - Index Herbariorum: A global directory of public herbaria and associated staff. New York Botanical Garden's Virtual Herbarium. <http: sweetgum.nybg.org.ih> (retrieved on December 2018).

Tison J.M. \& De Foucault B., 2014 - Flora Gallica. Flore de France. Biotope edition, Mèze.

Tison J.M., Jauzein P. \& Michaud H., 2014 - Flore de la France méditerranéenne continentale. Naturalia Publications, Turriers: 469-470.

Tutin T.G., 1980 - Gastridium Beauv. In: Flora Europaea. Tutin T.G., Heywood V.H., Burges N.A., Moore D.M., Valentine D.H., Walters S.M. \& Webb D.A. (eds.). Cambridge University Press, Cambridge, 5: 235.

Tzvelev N.N., 1976 - Grasses of the Soviet Union (Zlaki SSSR) part II. Nauka Publications, Leningrad. (English translation published for the Smithsonian Institution Libraries and the National Science Foundation, Washington, D.C., Amerind Publ, New Delhi, 1983).

Valdés B. \& Scholz H., 2009 - Poaceae (pro parte majore). Euro+Med Plantbase - the information resource for Euro-Mediterranean plant diversity. <http://ww2. bgbm.org/EuroPlusMed> (retrieved on February 2019).

WCSP, 2018 - World Checklist of Selected Plant Families. Facilitated by the Royal Botanic Gardens, Kew. $<$ http://wcsp.science.kew.org/> (retrieved on 3 May 2019). 
APPENDIX - Selected specimens examined.

Gastridium lainzii (Romero García) Romero Zarco SPAIN. Sevilla. Constantina. Carretera de la Puebla de los Infantes, km 12, 17 June 1978, E. Tello (SEV digital image! sub G. phleoides subsp. lainzii rev.); Córdoba. Entre Rute y Carcabuey, a 7 km de Rute, 17 June 1982, J.E. Pastor \& B. Valdés (SEV digital image!); Cádiz, loc. Puerto de Gáliz (Cádiz), 9 July 2017, J. López Tirado (UTV!); Nava de Cabra (Cabra, Córdoba), 29 June 2018, J. López Tirado (UTV! transitional form).

Gastridium phleoides (Nees \& Meyen) C.E.Hubb. MOROCCO. In Atlantis Medii montibus supra urbem Taza, 18 June 1925, R. Maire (RO! sub G. lendigerum). FRANCE. Levie (Corse), rive gauche du Fiumicicoli, en amont du pont de Pargula (route D59), 18 June 1995, R. Deschâtres (MSNM!). SPAIN. Ctra. Aldemaqueada Castellar de Santiago (Jaén), 31 May 2018, J. López Tirado (UTV!); Venta de Curro Fal (Sevilla), 1 June 2018, J. López Tirado (UTV!); Córdoba, loc. Cruce carretera Santo Domingo, 5 June 2017, J. López Tirado (UTV!). ITALY. Veneto: Colli Euganei (Padova), June 2001, $R$. Masin (MSNM!); Liguria. Varazze, 4 July 1923, G. Gresino (FI! sub G. lendigerum); Tuscany: In apricis insulae Gorgoniae, July 1840, P. Savi (FI! sub G. lendigerum); In promontorio Argentario, verso il telegrafo, 3 July 1886, E. Levier \& S. Sommier (FI! sub G. lendigerum); Isola del Giglio, fra il porto e il paese, 7 July 1898, S. Sommier (FI! sub G. lendigerum); Gorgona, sopra Cala Maestra, 18 August 1886, G. Arcangeli (PI! sub Gastridium); Insula Pianosa, 18 May 1909, S. Sommier (FI!, PI! sub G. lendigerum); Punta Ala, Grosseto, 19 July 2000, E. Banfi (MSNM! sub G. ventricosum); Mti di Castro, Loc. Campigliola, Manciano, 9 June 1015, A. Scoppola (UTV!); Lazio: Fra Monte Porcino e Riserva delle Saliere [Sezze], 8 August 1894, T.A. Baldini det. G. Lusina (RO! sub G. lendigerum subfo. luxurians Lusina); Velletri, Regione Morice, 21 July 1939, S. Senni (FI! sub G. lendigerum); Farfa-Toffia-Fara Sabina, 16 June 1959, B. Anzalone (RO! sub G. ventricosum); Isola di Zannone, Arcip. Ponziano, 22 May 1968, B. Anzalone (RO! sub G. ventricosum); Barbarano Romano (Viterbo), loc. Campecora, 17 July 2008, A. Scoppola (UTV! sub G. ventricosum); Sughereta di Fossanova, Priverno, 16 July 2017, A. Scoppola (UTV!); Mti di Castro, Ischia di Castro (Viterbo), 17 July 2017, $A$. Scoppola (UTV!); Piana di Cervaro, S. Giovanni Incarico (Frosinone), 2 June 2018, A. Scoppola (UTV!); Vigna di Valle, Bracciano (Roma), 10 June 2018, A. Scoppola (UTV!); Campania: Palmarola, 16 May 1900, A. Béguinot (FI! sub G. lendigerum); Scogli di S. Anna, Ischia, 22 June 1907, M. Guadagno (PI! sub G. lendigerum); Sul Monte Pendolo sopra Gragnano, 6 July 1907, G. Pellanda (PI! sub G. lendigerum var. scabrum); Tifati (Puccianello), 3 July 1927, L. Grande (RO! sub G. ventricosum); Acciaroli, Cilento, 4 May 2004, L. Rosati (HLUC! sub G. ventricosum); Caserta (CE), Casino Leonetti, 5 May 2016, A. Stinca (PORUN!); Calabria: Presso Nicastro, 12 June 1899, A. Fiori (FI! sub G. lendigerum); San Giovanni in Fiore, a destra del Neto, 18 September 1910, G. Lopez (FI! sub G. lendigerum); Dintorni di Catanzaro, 5 June 1983, Andrea Fiori (FI! sub G. lendigerum); Pizzuti,
Cropolati, Cosenza, 2 June 1984, D. Puntillo (CLU! sub G. ventricosum); Fiumara Trionto, Crosia, Cosenza, 10 June 1993, L. Bernardo \& C. Gangale (CLU! sub G. ventricosum); Eastern part of Aspromonte, Gole Fiumara La Verde, Reggio Calabria, 6 June 1997, VIII Iter Mediterraneum OPTIMA n. 718 (CLU! sub G. ventricosum); Dalia Nuova, Aspromonte, 8 July 1999, E. Banfi (MSNM! sub Gastridium); Aiello Calabro, Loc. Petrone, 1 June 2005, V. Pignataro (CLU! sub G. ventricosum); Sersale (Catanzaro), Contrada Cippino Sottana, 5 June 2008, G. Galasso (MSNM! sub G. ventricosum); Apulia: Leucaspide, April 1877, D. Profeta (FI! sub G. lendigerum); Montagna dell'Oro, presso la Palascia, Otranto, May 1880, $D$. Profeta (FI! sub G. lendigerum); Capo d'Otranto (Lecce), 13 August 1986, E. Banfi (MSNM! sub G. scabrum); S. Isidoro (Lecce), 22 May 1991, E. Banfi (MSNM! sub G. ventricosum); Salento (Lecce), Ugento, 13 August 1992, G. Galasso (MSNM! sub G. ventricosum); Sicily: Sicilia, 1841, F. Parlatore (FI! sub G. lendigerum). Palermo in collibus, s.d., V. Riccobono (PI! sub G. australe); Sotto il paese di Pollina, Madonie, 23 May 1989, F.M. Raimondo \& G. Certa (PAL! sub G. ventricosum); Salina, Isole Eolie, 1 June 1990, E. Lattanzi (UTV! sub G. ventricosum); Sardinia: Gallura, Capo Ferro, Tre Monti, June 1893, A. Vaccari (B digital image!); Selva dei Sette Fratelli, July 1900, F. Cavara \& R. Pirotta (FI! sub Koeleria cristata); Geremeas [Quartu Sant'Elena], 1-4 June 1904, A. Casu (RO! sub G. lendigerum forma); Telti, km 21 SS Settentrionale Sarda a Ovest del paese, 21 June 1972, S. Steinberg \& C. Ricceri (FI! sub G. ventricosum); Lula, Monte Albo, Nurai, 22 June 1978, I. Camarda (SS! sub G. ventricosum); Mte Arci, Oristano, 25 July, 1981, E. Banfi (MSNM! sub G. ventricosum).

Gastridium scabrum C.Presl - TURKEY. Bornova, Izmir, 2 July 2019, A. Scoppola (UTV! specimen obtained from caryopses provided by the U.S. National Plant Germplasm System [1 April 1953, R.K. Godfrey] and germinated in pot. ITALY. Liguria: Bordighera, 7 July 1901, C. Bicknell (FI!); Ibidem, 21 July 1903, L. Pollini (PI!); Lazio: Tivoli, Bagni dell'Acqua Solfa: Lago Colonna, 20 July 1895, A. Pappi (RO!); Civitavecchia, 10 July 1900, G. Parisi (RO!); S. Severa, Rio Fiume, 9 July 2017, A. Scoppola (UTV!); Tolfa, loc. Monte Rosso, lungo la SP 3B, 23 July 2017, A. Scoppola (UTV!); San Giovanni Incarico (Frosinone), 3 June 2018, A. Scoppola (UTV!); Basilicata: Trivigno, 3 July 1979, L. Aita (HLUC!); Calabria: Marina di Cotrone a Scarzo, 21 June 1911, G. Lopez (FI! sub G. lendigerum); Via del mare, pr. Crotone, Catanzaro, 26 September 1935, G. Lusina (RO sub Gastridium); Cosenza, Cetraro, Loc. Santa Lucia, 17 June 2005, C. Antonucci \& L. Peruzzi (CLU! sub G. ventricosum); Apulia: Torre del Monte, 23 August 1904, E. Carano (RO! sub G. lendigerum var. scabrum); Sicily. Nebrodi: Fiume Troina, 9 June 1990, F.M. Raimondo et al. (PAL!); Bosco Favara, Montemaggiore Belsito (Palermo), 1 May 1991, S. Buscaglia (PAL!).

Gastridium ventricosum (Gouan) Schinz \& Thell. - ENGLAND. Inter Slinfold et Horsham in comitatu Sussexia, 15 August 1883, J.W. White (RO! sub G. lendi- 
gerum). CROATIA. Isola di Veglia, Quarnaro, 12 August 1920, G. Lusina (RO! sub G. lendigerum); Lussingrande, 24 May 1945, G. Lusina (RO! sub G. lendigerum). FRANCE. Bougon près de La Mothe-Saint-Héray (DeuxSèvres), 30 July 1853, C. Sauzé \& P.N.Maillard (B digital image! sub G. lendigerum). SPAIN. Córdoba, loc. Torre del Beato (Córdoba), 5 June 2017, J. López Tirado (UTV! sub G. phleoides cfr.). ITALY. Liguria: Liguria occidentale (Imperia), Colle Merello sopra Bordighera, 23 June 1993, G. Barberis, G. Paola \& S. Peccenini (GE! sub Gastridium); Tuscany: Ponte del Forno, valle del Frigido, 20 June 1936, P. Pellegrini (PI! sub G. lendigerum); Duna Feniglia, Orbetello, 19 June 2009, M. Landi (SIENA!); Promontorio di Punta Falcone, 19 June 2015, D. Cantini (SIENA!); Mti di Castro, loc. Campigliola, Manciano, 27 June 2015, A. Scoppola (UTV!); Lazio: Isola di Zannone, Arcip. Ponziano, 22 May 1968, B. Anzalone (RO!); Colle Piseglio, Arcinazzo, 25 June 2011, E. Lattanzi (UTV!); Sughereta di Tuscania (Viterbo), 8 June 2017, $A$. Scoppola \& M. Rodriguez Carracedo (UTV!); Abruzzo: Gran Sasso, Colle S. Marcello, Fano Adriatico (Teramo), 17 June 2010, E. Lattanzi (UTV!); Campania: In arvis Sannio, Avellino, September 1848, s.n. (FI! sub Milium lendigerum); Basilicata: Presso Matera, 7 June 1913, A. Fiori (FI! sub G. lendigerum); Calabria: Torre di Ruggero (Catanzaro), 26 July 1983, D. Puntillo (CLU!); Pollino, Castrovillari, 6 June 1996, L. Bernardo \& N. Passalacqua (CLU!); Apulia: Isole Tremiti, S. Domino, 30 May 2005, E. Banfi (MSNM!); Sicily: Monte Cofano, 31 May 1990, F.M. Raimondo et al. (PAL!); Gangi, Gurghi di monte Zimmarra, 8 June 1990, F.M. Raimondo et al. (PAL!); Sardinia: Azienda "Le Progionette", Capo Caccia, Alghero, 6 June 2001, A. Scoppola (UTV!). 